\title{
Lumen
}

Selected Proceedings from the Canadian Society for Eighteenth-Century Studies

\section{Bondage and Slavery in Eighteenth-century Poetry by Women}

\section{Barbara Darby}

Volume 14, 1995

URI : https://id.erudit.org/iderudit/1012506ar

DOI : https://doi.org/10.7202/1012506ar

Aller au sommaire du numéro

Éditeur(s)

Canadian Society for Eighteenth-Century Studies / Société canadienne d'étude du dix-huitième siècle

ISSN

1209-3696 (imprimé)

1927-8284 (numérique)

Découvrir la revue

Citer cet article

Darby, B. (1995). Bondage and Slavery in Eighteenth-century Poetry by Women. Lumen, 14, 25-35. https://doi.org/10.7202/1012506ar d'utilisation que vous pouvez consulter en ligne.

https://apropos.erudit.org/fr/usagers/politique-dutilisation/ 


\section{Bondage and Slavery in Eighteenth-century Poetry by Women}

Feminist analyses of eighteenth-century attitudes towards gender - in studies such as those by Katharine Rogers, Alice Browne, and Donna Landry, or anthologies by Bridget Hill, Moira Ferguson, Roger Lonsdale, Joyce Fullard, and Vivien Jones ${ }^{1}$ - present female experience as it is often characterized by unequal participation in such institutions as education, marriage, the legal system, and government. Along with a growing body of work now available that includes eighteenth-century expressions of protest against the inferior status of women, twentiethcentury criticism has constructed a general view of eighteenth-century feminism and the concerns of women writing about their place in society. However, in studies of feminist voices that emerge from a society rigidly stratified along lines of class and race as well as gender, it is important to observe that different forms of hierarchy and status are often simultaneously in place and that the claims of subordinate positions within them can be competitive. Kristina Straub describes the difficulty of maintaining an adaptable critical perspective: categories of difference race, class, gender, and sexual identity - can be 'integrally related, even cojoined' and as critics we may feel inclined to 'labour to put them together': ' $[t]$ he difficulty for feminist critics often lies in how to articulate relations between forms of difference without treating them as interchangeable. ${ }^{2}$ Poetry by eighteenth-century women writers is poetry about difference, but occasionally protests against female subordination and oppression appeal to other forms of hierarchy that are firmly and unquestionably in place; the metaphors of confinement and slavery that recur in this feminist poetry should be contextualized, as they often are not, in terms of a matrix of competing hierarchies and positions of power.

One of the prominent poetic techniques used by women writers who specifically denounce gender-biased intellectual and marital hierarchies is the use of metaphors of entrapment, confinement, bondage, and slavery to describe women's social position, or lack thereof. Images of the enslaved woman or enslaved female mind abound in poetry written throughout the century. Perceived intellectual inferiority is figured as 
the enslavement of a mind or the fettering of thought, the result not of biology but of concerted efforts to maintain male dominance over women. The position of wife is similarly depicted as one of enchainment, confinement, and domination by men. Mary Chudleigh, Elizabeth Thomas, Sarah Egerton, Elizabeth Tollet, and Mary Leapor, to name only a few writers, describe women in these terms. Chudleigh, in 'To the Ladies' (1703) writes, 'Wife and servant are the same, / But only differ in the name,' and in The Ladies Defence describes women as 'Slaves' to men's 'Luxury and Pride. ${ }^{3}$ Egerton feels that 'Poor womankind's in every state a slave' ('The Emulation' [1703] 4). Thomas's 'On Sir J-Ssaying in a Sarcastic Manner, My Books would make me Mad. An Ode' (1722) dramatizes a slave speaking to her superiors about husbands who employ wives fulltime (15-23) and Tollet writes of 'servile tasks,' 'the domestic chain,' and 'servitude' $(2,8,9)$ in Hypatia (1724). Leapor discusses '[a] wife in bondage' (3) in 'An Essay on Woman' (1746):

Though nature armed us for the growing ill With fraudful cunning and a headstrong will;

Yet, with ten thousand follies to her charge,

Unhappy woman's but a slave at large. (57-60)

Envisioning women as bound up, confined, and controlled mentally, even as owned human commodities, these women offer strong voices of protest again the inferior social position of women. ${ }^{4}$

However, while this metaphor expresses a general sense of inequality, it can, in other instances, also invoke a reflection on forms of bondage and slavery that are deemed appropriate, or can be contrasted with the literal and distinctive suffering of working-class and non-white women. Many discussions about female 'slavery' do not reflect these different uses of metaphor. Donna Landry mentions several uses of the slavery metaphor in feminist poetry, but differences between metaphoric and literal senses of confinement are only explicit in her discussion of Phillis Wheatley's writing 'literally as a slave' (238). Alice Browne observes instances where 'pro-woman writing' is compared to abolitionist writing (129-30), but although she writes about the political efficacy of this equation, she does not comment on the contradictions in such a comparison, or the instances where the issues of gender and race are opposed. It is true, as Moira Ferguson writes in First Feminists, that 'slavery was a favourite metaphor in ... descriptions of women's lives' (34), but Ferguson is wrong to suggest that before the nineteenth century 'slavery was not perceived as a feminist issue by writers who addressed discrimination against women' (33). Slavery was perceived as a feminist issue by women writers addressing female discrimination, but the aim was not 
always to address the problems of working-class women or people of different races.

Without a differentiation between observations about gender-based inequality and servitude that derives from class or racial discrimination, many poets who use the image of a woman in bondage - and some critics who follow them - occlude the real position of the inferior slave or working-class woman, a position that is unacceptable when applied to the female speaker in many poems, but which is nonetheless necessary in order to provide a point of distinction between the speaker and less-privileged women. The persuasiveness of such writing depends on the reader's recognition that confinement is a violence incommensurate with the intellectual and moral capacity of women. However, not all forms of confinement and slavery that female poets discuss are exclusively metaphoric. Two uses of the 'woman in bondage' image are particularly of interest because of their contrast of literal and metaphoric bondage: one, where the metaphor of the confined female mind is depicted as superior to the mind of a lower-class woman or slave which is more deserving of its literal bondage, the other where the oppressions of gender, class, and race are rooted in literal and physical circumstances. I do not intend to conflate oppression related to race or class; in many uses of the metaphor of bondage and slavery, both economic and racial inferiority may well be the intended referents.

In specific poems, the image of bondage and confinement is used by the speaker in order to differentiate herself from another type of woman, an expression of difference that is at once hierarchical and tendentious, forging distinctions between 'natural' inferiority and the less physical, more ideological confinement of the British woman by marriage or by a poor education. Speakers making such distinctions tend to use rhetorical strategies similar to those identified as serving the interests of male domination: notions of inherent weakness, religious legitimation, and the benefits of accepting inferiority. While this does not dismiss any argument against the oppression of women, one must appraise the positions from which such arguments emerge. The 'woman in bondage' image therefore intersects the sometimes competing positions of class, race, and gender.

A poem by B-ll M-rt-n (1726?) specifically asserts that there is an inherently inferior state of mind that is accustomed to, perhaps even deserving of, enslavement. This is not the speaker's present intellectual capacity, however. She is humble in her rejection of physical and material advantages, but indicates that a radical change in her mental state is required, to accompany the submissive position of women. Here is her poem: 
I ASK not wit, nor beauty do I crave,

Nor wealth, nor pompous titles wish to have;

But since 'tis doomed, in all degrees of life

(Whether a daughter, sister, or a wife),

That females shall the stronger males obey,

And yield perforce to their tyrannic sway;

Since this, I say, is every woman's fate,

Give me a mind to suit my slavish state. (p. 105)

The poem opens with the familiar argument that women do not have the access to superior position or signs of success (wealth, titles) that they deserve. However, while many women who experience social and educational inferiority demand a change in material and social circumstances, this speaker instead asks for an inferior mind that will be appropriate to her subjugation. The poem ultimately adopts the same line of reasoning used to support male domination: the hierarchical structure of society reflects the intellectual advancement of its various members. In this case, however, class and racial hierarchies must be maintained in order for this speaker to deplore inappropriate, genderrelated inequality for those who might otherwise expect wealth and title. One reading of this speaker's observation that status and mental states should be suited to one another is that she rejects the ways powerlessness can be constructed and legitimated. However, the notions that some forms of oppression are acceptable when the oppressed are kept ignorant, and that a hierarchy of status is inevitable, are both present in this poem.

An anonymous poem by 'A Lady,' 'Woman's Hard Fate' (1733), relies on the concept of a natural predisposition for bondage. The speaker begins by decrying the subjugation of women to men and to disastrous fate:

HOW wretched is a woman's fate,

No happy change her fortune knows;

Subject to man in every state,

How can she then be free from woes? (1-4)

Confinement is enforced by father and 'lordly brother' $(5,7)$ who keep her 'captive' and 'control her will' $(8,6)$, suggesting that the woman is perpetually a prisoner in some gender-specific panopticon, controlled by 'jealous eyes' and 'watchful' lording $(6,7)$. Father and brother are replaced by 'tyrant husband' (9). The husband, formerly woman's 'slave' (12), now becomes sovereign through matrimony's 'fatal bondage' (13). 
This speaker assumes that women are by nature predisposed to fall in love and leave one form of subordination only to re-inscribe themselves in a confining situation that will replace the family with marriage. But while some writers might urge women to counter physical confinement by exploring intellectual freedom, 'A Lady' asks the reverse:

Oh cruel powers, since you've designed

That man, vain man, should bear the sway,

To a slave's fetters add a slavish mind,

That I may cheerfully your will obey. (21-24)

Like the speaker in M-rt-n's poem, this speaker appeals not only to the inherent predispositions of women, but also to some essential nature of racial or class identity. Like M-rt-n, this speaker appeals to the dictates of higher powers, as if assenting to a spiritual source of female inferiority. Obedience then becomes a matter of wishing not to know any better, exactly the argument so often rejected by women when they are advised to accept their fates or to reject learning that will only make them unhappy. Male superiority is depicted as something pre-determined; female inferiority is best accommodated by the old dictum that ignorance is truly bliss. This can be secured by a decline in mental capacity that is envisioned as synonymous with servitude, and which was particularly equated with a non-white intellect, described by Hannah More even in the abolitionist poem The Slave Trade as 'dark and savage, ignorant and blind. ${ }^{5}$

In other poems, the metaphor of bondage is replaced by literal descriptions of oppression. The servitude of the working-class woman is a strong literal presence in Mary Collier's The Woman's Labour (1739), which was written in response to Stephen Duck's The Thresher's Labour (1730). Collier, a washer-woman and a poet, was all too familiar with hierarchy and the problems of the female working class. Her poem employs the image of a woman in bondage in a context which acknowledges, as other poems do not, practical impediments to the luxury of demanding education, let alone pursuing it. For this speaker, slavery is a function of her status as a working-class woman, rather than a metaphor for her experience of denial. She juxtaposes her position as a member of the working class with the more rhetorical constructions of the slave that one finds in Duck. Her lines come 'From her, who ever was, and's still a Slave. ${ }^{6}$ But unlike other speakers who discuss bondage, this speaker describes in detail her own position in a household and in society, a position affecting her on the level of the body as well as the mind, in real rather than metaphoric ways. 
The speaker draws attention to class difference by noting that a life of 'Drudgery' (8) without education is 'the Portion of poor Woman-kind' (10). While 'poor' in this context may refer to women of any class, the poem goes on to legitimize this speaker's claims of class-based subjugation by material descriptions of work and the pain suffered because of it, both of which belie the dream that women from 'first Extraction ... refin'd, / Could never be for Slavery design'd' (13-14). The permission to speak becomes an issue in this poem, a response to Duck's scorn that refuses to 'let our hapless Sex in Silence lie / Forgotten, and in dark Oblivion die' (38-39). As a working woman, the speaker asserts that her only freedom exists in her freedom of expression, which she invokes to discount Duck. In their desire to speak, she argues, men and women are identical, though it is 'The only Privilege our Sex enjoy' (74).

The speaker clearly differentiates between men's and women's work and describes her tasks in both agricultural and domestic spheres; retiring from the fields, she and women like her return to the unpaid labour of the home, and here again Duck is forced into the position of advantage, as the 'you' whose coming prompts dinner preparation, sewing, and child care. Paid domestic labour is described in detail, as is a confrontation which occurs in addition to the intertextual confrontation with Duck. The speaker and her sister workers meet the lady of the house, revealing a gender-specific class distinction by showing women working for other women and indicating that, for this speaker at least, privilege or subjugation are functions of class more than gender. Confinement and pain are physical rather than metaphoric:

Until with Heat and Work, 'tis often known,

Not only Sweat, but Blood runs trickling down

Our Wrists and Fingers; still our Work demands

The constant Action of our lab'ring Hands. (84-87)

The speaker closes her poem with the observation that to 'rehearse all Labour is in vain' (235), for rehearsals do not prevent work being 'Brought in to make complete our Slavery' (212). The poem overflows with tasks and drudgery; one has a sense that the speaker's lamentation infringes on the time available for her labour. The poem's closing metaphor, comparing women to 'industrious Bees' (244), allies workers with owned commodities, working for 'sordid Owners' who reap their profits without recompense for 'Toil and Pains' (246-47). Collier's poem contains a note of personal conviction when she protests servitude, conviction that is vividly expressed in her descriptions of the slavery of the working class. 
The reference to 'sordid owners' cannot help but bring to mind the servitude of a slave class that was different from its owners because of inferior economic status and perceived racial inferiority. Even the most general references to bondage and enchainment in feminist poems may have appealed to readers attentive to the usual fate of a human cargo, "'tight-packed" in chains in [a] ship's steaming hold "like books on a shelf."'" Hannah More refers to the 'successive chains' of slaves (The Slave Trade 109), as does William Cowper in 'Sweet Meat has Sour Sauce.' Slavery was a lucrative business throughout the eighteenth century; there were thirty thousand black men and women in London by 1764 and this number continued to grow. ${ }^{8}$ This fact prompted abolitionist poetry and prose writing, as well as provided a political issue with which to ally considerations of women's place in society. However, racial subjection is occasionally referred to in feminist poetry as an institution that is appropriate for different cultures but is inappropriately a feature of the relationship between the sexes.

Collier's speaker, for example, implies that Duck is in the position of master/slave-owner when she compares his silencing of woman to that of other oppressors. She suggests that Britain need not perpetuate the practices of another culture which, by comparison, is less 'civilized' and therefore more likely to treat women badly. This speaker refuses to be silent on the grounds that

For none but Turks, that ever I could find,

Have Mutes to serve them, or did e'er deny

Their Slaves, at Work, to chat it merrily. $(76-78)^{9}$

One effort that Landry observes in abolitionist poems - the preservation of 'difference at the expense of the other's rationality' (239-40) - is evident in Collier's work, and in that of M-rt-n and 'A Lady,' who capitalize on a discourse of cultural and class differences in order to protest the dismissive treatment of some women. ${ }^{10}$

The literal image of servitude grounded in racial difference appears largely in abolitionist tracts, although these poems tend to be written by those with no personal experience of slavery. The voice of the slave is thus generally spoken indirectly; the protest of the non-British enslaved woman is difficult to locate otherwise. Phillis Wheatley's use of images of confinement, as Landry notes, emerges from a context of actual slavery which distinguishes it from those of other 'free' writers (217-53). 'The Story of Inkle and Yarico' (1726?), by Frances Seymour, Countess of Herford, although clearly written by an upper-class British woman, attempts to depict literal, racially based bondage at the same time as it offers a gender-conscious portrayal of a woman's plight when she is 
subject to male domination. ${ }^{11}$ Ferguson suggests that Seymour, 'in centre staging an African female protagonist ... allowed [herself] to air problems faced by female contemporaries' and was 'among the few writers to afford black females any kind of subjectivity for at least fifty years' (Subject to Others 73). In writing of Yarico's submission to Inkle, Seymour describes bondage that emphasizes the material, racially based bondage of a woman over other, more subtle depictions of gendered submission in the poem.

This gender-conscious anti-slavery poem only specifically protests slavery in its final lines, those spoken by the commodified non-white woman. The poem introduces the hero, Inkle, after he has landed on 'a barbarous coast' (12) where 'cruel natives thirsted for ... blood' (15). Discovered by a 'negro virgin' (24), Inkle is soon ensconced in an exotic domesticity enjoyed because of Yarico's devotion to his security. She hides him from the cannibals, brings him 'choicest fruits' (33) and clear water. The lovers exchange goods rather than words, she supplying pelts and feathers (familiar commodities of colonization) and he offering 'shells and painted flowers / That serve to deck the Indian virgins' bowers' (45-46). Yarico is 'th'attentive virgin' (58) and for her pains she is told that if she could return to Inkle's 'native country' (60), she would be adorned with 'softest silks' (61) such as distinguish Inkle from Yarico and the cannibals, signs for him of his superiority and of the colonial power of his race and nationality.

Yarico's submission and Inkle's sense of superiority place Yarico in danger once she spies and hails a European vessel to shore. Yarico is seen by Inkle as another 'doting virgin' (76), of which there are plenty at home; she is then sold to planters in Barbados. Yarico's pleading for Inkle to reconsider her plight (and that of their unborn child) refers not only to the literal slavery into which she is being sold, but also to the mental and emotional submission of woman to man. She pleads: "“Oh let me not in slavery remain, / Doomed all my life to drag a servile chain!"' (93-94). She pleads for a more desirable fate - being stabbed at Inkle's feet, blessing him for granting her death - but she is sold nonetheless. Both sexual and racial submission are evident in the poem, but its closing references to the confinement of slavery and its 'servile chain' emphasize that submission depicted throughout the poem takes a variety of forms on a spectrum that ranges from death to literal commodification, physical confinement, or emotional sacrifice. This final, pleading depiction of a woman suffering because of the combined prejudices against race and gender must certainly modify a general view of the entrapped or servile British woman.

It is not my purpose to dismiss as inaccurate or unimportant the use of the image of the woman in bondage as an image of protest in feminist 
poetry. Given the clearly subordinate role women had in marriage, in legal systems, the family, and other social institutions, the protest that emerges in poetry that scrutinizes the status of woman is significant. As Gary Kelly notes, even if the body of feminist writing grew over the century, the post-Revolutionary 'backlash' against women's issues involved a 'remasculinization' of British culture that was 'less tolerant and more suspicious of feminisms within the cultural revolution, more insistent in excluding women from the public and political sphere. ${ }^{12}$ Many women lent their voices either publicly or privately to a growing body of work that addressed the status of women in eighteenth-century British society. What is important is that discussions of gender take into account the emphasis on one source of oppression at the expense of other forms of experience that may similarly be characterized by inequality, such as experiences of class and racial servitude. Some feminist poetry of the eighteenth century manifests what Pierre Machery describes as a simultaneous use of the spoken and unspoken: '[e]ither all around or in its wake the explicit requires the implicit: for in order to say anything, there are other things which must not be said. ${ }^{13}$ The 'implicit' seems to be that a gender inequality for upper-class women is inappropriate, in part because the class divisions and racism that separate them from those 'beneath' them are appropriate.

Literary and critical practices must be scrutinized for their assumptions about status and the relative significance of institutionalized divisions based on gender, class, or race. When poets invoke such hierarchies to legitimize or protest forms of oppression, a context of competing values is often simultaneously invoked. In terms of critical practice, the important insights of feminist critiques of gender-related oppression can be made more complex when a matrix of values concerning gender, class, and race is considered. Where categories of difference and power intersect, it is clear that the rejection of particular types of ideological construction does not necessarily expose others as problematic.

\section{BARBARA DARBY \\ Queen's University}

\section{Notes}

1 Katharine M. Rogers, Feminism in Eighteenth-Century England (Urbana: U of Illinois P, 1982); Alice Browne, The Eighteenth Century Feminist Mind (Brighton: Harvester, 1987); Donna Landry, The Muses of Resistance (Cambridge: Cambridge UP, 1990); Eighteenth Century Women: An Anthology, ed. Bridget Hill (London: Allen and Unwin, 1984); First Feminists, ed. Moira Ferguson (Bloomington: Indiana UP, 1985); Eighteenth Century Women Poets, ed. Roger Lonsdale (Oxford: 
Oxford UP, 1989); British Women Poets, ed. Joyce Fullard (Troy, NY: Whitston, 1990); Women in the Eighteenth Century, ed. Vivien Jones (London and New York: Routledge, 1990). All subsequent references to these works will be cited by page number in the text.

2 Kristina Straub, Sexual Suspects (Princeton: Princeton UP, 1992) 151.

3 Lady Mary Chudleigh, 'To the Ladies,' Eighteenth-Century Women Poets 3, lines 1-2 (all subsequent quotations are from poets anthologized by Lonsdale, unless otherwise noted, cited by line number); Lady Mary Chudleigh, The Ladies Defence, The Poems and Prose of Mary, Lady Chudleigh, ed. Margaret J. M. Ezell (New York: Oxford UP, 1993) 15-40, line 520.

4 That the use of metaphors of imprisonment may be derived from personal experience or are merely a conventional mode of expression is suggested by the wide biographical variety of these writers. Lady Mary Chudleigh (1656-1710) married a man who would become a baronet. Elizabeth Thomas (1675-1731) was self-educated and, though courted by several men, was confined to nursing an invalid mother and spent time impoverished and confined for debt. Blain, Clements, and Grundy note in The Feminist Companion to Literature in English (New Haven: Yale UP, 1990) that Sarah Egerton (1670-1723) was 'evidently well-educated' (405). She is said to have petitioned for divorce from her husband on 'grounds of cruelty' (405). Elizabeth Tollet (1694-1754) grew up in the Tower of London. Mary Leapor (1722-46) was a labouring-class poet.

5 Hannah More, The Slave Trade, The Complete Works of Hannah More, 2 vol. (New York: Harper, 1835) 1:27-30, line 155.

6 Mary Collier, The Woman's Labour (Los Angeles: The William Andrews Clark Memorial Library, 1985), line 6. All subsequent quotations from Collier and Duck are from this edition of the poems, cited by line number. See also Donna Landry's discussion of Collier's work (56-77).

7 Three Black Writers in Eighteenth Century England, ed. Francis D. Adams and Barry Sanders (Belmont, CA: Wadsworth, 1971) 5.

8 For specific details about the eighteenth-century British slave trade, see Three Black Writers. Moira Ferguson's Subject to Others: British Women Writers and Colonial Slavery 1670-1834 (New York: Routledge, 1992) discusses anti-slavery literature in the eighteenth century.

9 Duck himself allies hard-working men with Black slaves, noting women's fear of men who appear to be 'Ethiopians' (14, italics in the original) because of the sweat and dust of their work. A description of cultural difference can be found in Chudleigh's The Ladies Defence (1701), but in this case it is used by the Parson of this poem as an argument for female submission:

If to your Lords you strict Allegiance pay'd, And their Commands submissively obey'd: If like wise Eastern Slaves with Trembling Awe You watch'd their Looks, and made their Will your Law, You wou'd both Kindness and Protection gain. (179-83)

Chudleigh's 'To the Ladies' similarly refers to a husband as '[f]ierce as an Eastern Prince' (9) whose wife, '[l]ike mutes, she signs alone must make, / And never any Freedom take' (13-14). 
10 Landry observes that even in abolitionist poems such as More's The Slave Trade and Yearsley's A Poem On The Inhumanity Of The Slave-Trade, the image of the slave was a 'crudely patched-together figure, a field of contradictions that reveal the workings of ideology, the desire to naturalize and recuperate the other while remaining uneasily alert to the threat of cultural difference' (238). Ferguson, in Subject to Others, writes that ' $[\mathrm{t}]$ he condition of white middle-class women's lives - their conscious or unconscious sense of themselves as inferior - set the terms of the anti-slavery debate' (3).

11 For another discussion of this poem and another by an anonymous writer on the same subject, see Ferguson, Subject to Others 79-90.

12 Gary Kelly, Women, Writing, and Revolution 1790-1827 (Oxford: Clarendon Press, 1993) 174.

13 Pierre Machery, 'The Text Says What It Does Not Say,' Literature in the Modern World: Critical Essays and Documents, ed. Dennis Walder (New York: Oxford UP, 1990) 217. Italics in the original. 